\title{
Expression Analysis of Interferon-Stimulated Gene 15 in the Rock Bream Oplegnathus fasciatus against Rock Bream Iridovirus (RSIV) Challenge
}

\author{
Kyung-Hee Kim, In Jung Yang, Woo-Jin Kim, Choul-Ji Park, Jong-Won Park, Gyeong Eon Noh, \\ Seunghyung Lee, Young Mee Lee, Hyung Kyu Hwang and Hyun Chul Kim \\ Genetics and Breeding Research Center, National Institute of Fisheries Science (NIFS), Geoje 53334, Republic of Korea
}

\begin{abstract}
Interferon-stimulated gene 15 (ISG15) is known to interfere with viral replication and infection by limiting the viral infection of cells. Interferon-stimulated gene 15 (ISG15) interferes with viral replication and infectivity by limiting viral infection in cells. It also plays an important role in the immune response. In this study, tissue-specific expression of ISG15 in healthy rock bream samples and spatial and temporal expression analysis of rock bream ISG15 (RbISG15) were performed following rock bream iridovirus (RSIV) infection. RbISG15 expression was significantly higher in the eye, gill, intestine, kidney, liver, muscle, spleen, and stomach, but low in the brain. There were particularly high levels of expression in the liver and muscle. RbISG15 expression was also examined in several tissues and at various times following RSIV infection. ISG15 expression increased within $3 \mathrm{~h}$ in the whole body and decreased at $24 \mathrm{~h}$ after infection. In addition, temporal expression of several tissues following RSIV infection showed a similar pattern in the muscle, kidney, and spleen, increasing at $3 \mathrm{~h}$ and decreasing at $72 \mathrm{~h}$. These results suggest that ISG15 plays an important role in the immune response of rock bream. Overall, this study characterizes the response of RbISG15 following RSIV infection.
\end{abstract}

Key words : Rock bream, Oplegnathus fasciatus, Gene expression, Rock bream iridovirus (RSIV), IFN-stimulated genes (ISGs)

\section{INTRODUCTION}

The rock bream Oplegnathus fasciatus belongs to the family Oplegnathidae and is widely distributed in the Indian and Pacific Oceans, including Korea, Japan, Taiwan, and Hawaii. Adults inhabit coastal rocky reefs, while juveniles associate with drifting seaweed and feed on zooplankton. It is an economically important resource in the fishing industry in Korea (Oh et al., 2007; Lee et al., 2016). Due to the rapid development of the aquaculture industry in recent years, the spread of bacterial and viral diseases has resulted in economic losses, including massive losses and reduc- tions in productivity (Jung \& Oh, 2000; Lee et al., 2016).

Rock bream iridovirus (RSIV) infection has been reported in marine cultured fish in Korea, Japan, China, Taiwan, and Thailand (Inouye et al., 1992; Chua et al., 1994; Kasornchandra \& Khongpradit, 1997; Miyata et al., 1997; Jung \& Oh, 2000). This virus is known to cause high mortality and result in economic losses (Jung \& Oh., 2000). Rock bream infected with RSIV become lethargic, and exhibit severe anemia, enlargement of the spleen, necrosis of the kidney and spleen, and petechiae of the gills (Inouye et al., 1992; Jung et al., 1997; Nakajima \& Maeno, 1998).

The immune system is a physiologically important sys-

\footnotetext{
Manuscript received October 7, 2017, Received in revised form November 13, 2017, Accepted December 18, 2017

${ }^{\dagger}$ Corresponding Author : Hyun Chul Kim, Genetics and Breeding Research Center, NIFS, Geoje 53334, Republic of Korea. Tel: +82-55-639-5814, Fax: +82-55-639-5809, E-mail: hckimgnu@ korea.kr

This is an Open Access article distributed under the terms of the Creative Commons Attribution Non-Commercial License (http:// creativecommons.org/licenses/by-nc/3.0) which permits unrestricted non-commercial use, distribution, and reproduction in any medium, provided the original work is properly cited.
} 
tem in the defense against pathogen invasion and to maintain homeostasis in the defense against antigens, external factors that invade organisms. Adaptive immunity is the immune response in which antigen-specific immune cells are activated and react with antigens through specific receptors. The generation of antibodies against a particular pathogen takes a day or several days (Medzhitov \& Janeway, 1997; Magnadottir et al., 2006). Moreover, because there is a delay before the initial adaptive immune response takes effect, the innate immune response plays a critical role in the control of infections during this period (Lee et al., 2016).

The type I interferon (IFN) system plays a critical role in innate antiviral immunity in fish (Collet \& Secombes, 2002; Schultz et al., 2004; Robertsen, 2006). In this system, direct antiviral responses are carried out by induction of hundreds of IFN-stimulated genes (ISGs) (Sarkar \& Sen GC, 2004). The 15 kiloDalton IFN-stimulated gene (ISG15) was the first identified ISG, and forms covalent conjugates with cellular proteins (Farrell et al., 1979; Loeb and Haas, 1994). ISG15 activity occurs through the covalent conjugation (ISGylation) of the LRGG motif, situated at the Cterminal end of all ISG15 proteins, to cellular or viral proteins (Loeb \& Haas, 1992; Dao \& Zhang, 2005). Extracellular ISG15 displays cytokine-like functions by inducing IFN-g in T-cells and stimulating natural killer cell proliferation (D’Cunha et al., 1996). Overexpression of ISG15 in IFN-a/b receptor knockout mice attenuates Sindbis viral infection and ISGylation was shown to be responsible for this antiviral effect (Lenschow et al., 2005).

Fish ISG15 sequences have been identified in turbot (Scophthalmus maximus), olive flounder (Paralichthys olivaceus), tongue sole (Cynoglossus semilaevis), rock bream (Oplegnathus fasciatus), Northern snakehead (Channa argus), black rockfish (Sebastes schlegelii), Atlantic cod (Gadus morhua) and Atlantic halibut (Hippoglossus hippoglossus). In addition, several ISG15 members have been studied in various defense mechanisms linked to pathogen infection (Seppola et al., 2007; Baeck 2008; Motoshige et al., 2011; Øvergård et al., 2012; Lin et al., 2015; Moreno et al., 2016).

In this study, we examined the expression patterns of ISG15 in several rock bream tissues. In addition, we analyzed the temporal expression profile of RbISG15 in immediate and continuous immune responses following RSIV infection. Our results improve our understanding of the distribution and the functional roles of ISG15 against viral infection.

\section{MATERIALS AND METHODS}

\section{Sample preparation}

Rock bream (Oplegnathus fasciatus) was obtained from the Genetics and Breeding Research Center of the National Institute of Fisheries Science (NIFS, Geoje, Republic of Korea) and maintained under a natural photoperiodin 30ton tanks. Tissue samples were prepared from various tissues, including brain, eye, gill, intestine, kidney, liver, muscle, spleen, and stomach, obtained from healthy rock bream (total length approximately $19 \mathrm{~cm}, 2$ years old) and stored at $-80^{\circ} \mathrm{C}$ until required. Whole body samples were also prepared from healthy rock bream (total length approximately $10 \mathrm{~cm}, 5-6$ months old). Deformed and diseased fish were excluded from all experiments. Fish were acclimatized to the experimental conditions for 1 week before the start of the experiment. Tissue collection and pathogen injection were conducted on anesthetized fish and samples were collected under aseptic conditions.

\section{Viral challenge}

The RSIV challenge experiment was conducted by randomly selecting rock bream specimens, dividing them into challenge and control groups, followed by injection with $100 \mu \mathrm{L}$ of RSIV suspension (10 2 TCID50 virus/fish) or phosphate-buffered saline (PBS), respectively (Umasuthan et al., 2013). Each group was maintained at a temperature 
of $20^{\circ} \mathrm{C}$ in a recirculation system, without flow and feeding. Samples from the gill, kidney, liver, muscle, spleen, and whole body were collected at $0,3,6,12$, and $72 \mathrm{~h}$ post-injection and frozen in liquid nitrogen. All samples were obtained and analyzed in triplicate and samples were ground using a homogenizer for RNA extraction.

\section{RNA extraction and reverse transcription-polyme-} rase chain reaction (RT-PCR)

Total RNA from the rock bream specimens was extracted using TRI solution (BSK-Bio Co.) according to the manufacturer's protocol. After extraction of total RNA, DNase-I (Sigma-Aldrich) was used to eliminate genomic DNA contamination. Total RNA was spectrophotometrically (BioTek, Gen 5.2) evaluated for quantity and quality and stored at $-80^{\circ} \mathrm{C}$ until further use. The isolated RNA was converted into complementary DNA (cDNA) using a Transcriptor First Strand cDNA Synthesis Kit (Roche Ltd., Switzerland). The amplification was performed with Solg ${ }^{\text {TM }}$ Taq DNA Polymerase (SolGent Co., Ltd.) in a My Cycler Thermal Cycler (Bio-Rad Laboratories Inc., Hercules, CA, USA) using the following parameters: denaturation at $95^{\circ} \mathrm{C}$ for $5 \mathrm{~min}$, followed by 35 cycles of denaturation at $95^{\circ} \mathrm{C}$ for $30 \mathrm{~s}$, annealing at $58^{\circ} \mathrm{C}$ for $30 \mathrm{~s}$, and elongation at $72^{\circ} \mathrm{C}$ for $30 \mathrm{~s}$. The amplified PCR products were analyzed by electrophoresis on a $1.5 \%(\mathrm{w} / \mathrm{v})$ agarose gel. Specific primers for rock bream ISG15 were designed using the Primer 3 program (Table 1). Relative amounts of each mRNA were quantified by dividing by the density of a housekeeping gene (Cho et al., 2006).

\section{Quantitative real-time PCR (qRT-PCR)}

qRT-PCR (ABI 7500, Applied Biosystems) was performed on rock bream samples to quantify the expression of ISG15. The primer pairs used for qRT-PCR amplification of the internal fragments of these genes are listed in Table 1. Isolated RNA was converted into cDNA using a
Transcriptor First Strand cDNA Synthesis Kit. RNA was converted to cDNA (100 ng/ $\mu \mathrm{L})$ and used as a template for qRT-PCR. The Fast SYBR Green PCR Master Mix (Applied Biosystems) was used for the reaction, with the following conditions: an initial denaturation step for $20 \mathrm{~s}$ at $95^{\circ} \mathrm{C}, 40$ cycles of $3 \mathrm{~s}$ at $95^{\circ} \mathrm{C}$ and $30 \mathrm{~s}$ at $60^{\circ} \mathrm{C}$, followed by a final dissociation stage. One microliter of cDNA was amplified in a $20-\mu \mathrm{L}$ reaction using Fast SYBR Green PCR Master Mix with each primer at a final concentration of $500 \mathrm{nmol} / \mathrm{L}$. The $2^{-\Delta \Delta \mathrm{Ct}}$ method was used to normalize differences in the amounts of total cDNA in the reaction using actin as an internal standard control (Pfaffl, 2001). The normalized value for ISG15 was then calibrated to the value for the brain or RSIV injection at $0 \mathrm{~h}$, which was assigned a value of 1 , by the standard curve method (Applied Biosystems).

\section{Statistical analysis}

The ISG15 mRNA levels were normalized to those of an internal control gene. The statistical analyses of gene expression were performed using one-way analysis of variance. Significant differences from control values were determined at $p<0.05(*)$ and considered extremely significant at $p<0.01(* *)$. All results are represented as the mean

\section{Table 1. Oligonucleotide primers used in this study}

\begin{tabular}{ccc}
\hline \hline $\begin{array}{c}\text { Primer } \\
\text { name }\end{array}$ & Sequence (5'-3') & $\begin{array}{c}\text { GenBank } \\
\text { accession } \\
\text { no. }\end{array}$ \\
\hline $\begin{array}{ccc}\text { ISG15- } \\
\text { qRT-1F }\end{array}$ & $\begin{array}{c}\text { AAGCTGGTCTTT- } \\
\text { GTCAACGG }\end{array}$ & \\
\cline { 1 - 2 } ISG15- & TGAG48677 \\
qRT-1R & GAATGTAGC & \\
\cline { 1 - 2 }$\beta$-actin- & AGCCAACAGGGAGAA- & \\
F & GJ975145 \\
\cline { 1 - 2 }$\beta$-actin- & TGATCTTCATGGTG- & \\
$\mathrm{R}$ & GATGGG & \\
\hline
\end{tabular}


\pm standard error of at least three independent replicates.

\section{RESULTS}

\section{Expression analysis of rock bream ISG15 from} various tissues

To determine the function and localization of rock bream ISG15, we evaluated the expression of ISG15 in various tissues from healthy rock bream (total length approximately $19 \mathrm{~cm}, 2$ years old) by qRT-PCR. ISG15 was highly expressed in the liver, muscle, spleen, and gill. When standardized to the brain (1.0-fold) of healthy rock bream, ISG15 mRNA levels were increased in the eye (2.4-fold), gill (15.9-fold), intestine (5.4-fold), kidney (2.4-fold), liver (54.7-fold), muscle (54.7-fold), spleen (14.8-fold), and stomach (2.4-fold). These results show that ISG15 mRNA expression differs significantly in different tissues (Fig. 1;

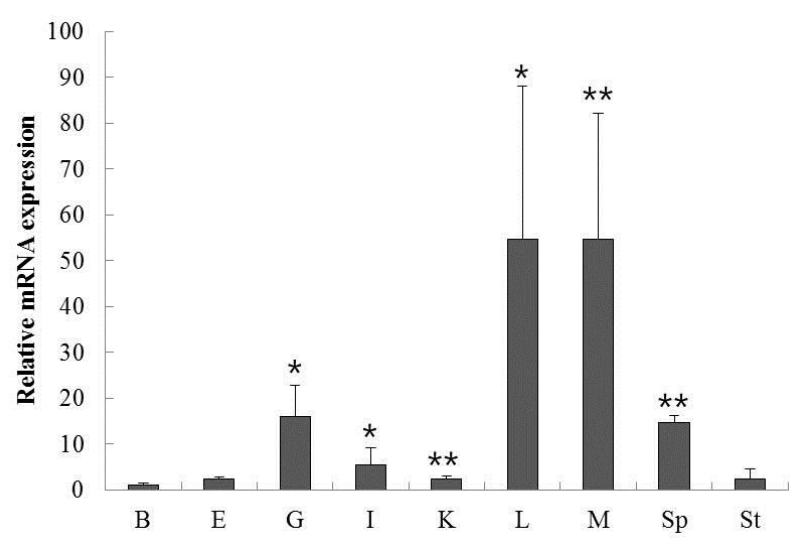

Fig. 1. Expression analysis of interferon-stimulated gene 15 (ISG15) in different tissues in healthy rock bream. ISG15 expression in different tissues was determined by quantitative real time polymerase chain reaction (qRT-PCR). The expression levels of beta actin and ISG15 in the brain were set as 1. B, brain; E, eye; G, gill; I, intestine; K, kidney; L, liver; $\mathrm{M}$, muscle; Sp, spleen; and St, stomach. All assays were performed in triplicate. The error bars represent the standard deviations for triplicate samples. Asterisks indicate statistically significant differences $\left({ }^{*} p<0.05 ;{ }^{* *} p<0.01\right)$ compared with the brain. supplementary Table 1).

2. Expression profile of ISG15 following RSIV challenge

To investigate the function of ISG15 in the immune response to viral infection, we assessed the expression of the gene using RT-PCR in a time course of whole rock bream infected with RSIV. ISG15 was ubiquitously expressed at all time points, but significantly increased at $12 \mathrm{~h}$ (Fig. 2A). qRT-PCR was performed to quantify the expression of ISG15 (Fig. 2B). As shown in Fig. 2B, although ISG15 expression remained at almost basal levels until $6 \mathrm{~h}$ postinfection (0.8-fold), it increased exponentially at $12 \mathrm{~h}$ postinfection (2.8-fold) and was reduced at $24 \mathrm{~h}$ post-infection.

Characterization of the temporal patterns of ISG15 mRNA expression in several tissues, including the gill, liver, muscle, and spleen, during pathogen infection was performed via qRT-PCR analysis. Gene expression was normalized to actin and $0 \mathrm{~h}$ expression in several tissues and calibrated to the assigned value of 1 by the standard curve method. The real-time PCR data analyzed by the $2^{-\Delta \Delta \mathrm{Ct}}$ method indicated that expression challenge with RSIV resulted in a significant increase in ISG15 mRNA expression in several tissues (Fig. 3A-3C). In particular,

\section{Supplemental Table 1. Average $C_{T}$ values of tested ISG15 in different tissue samples}

\begin{tabular}{cc}
\hline \hline Sample name & $\mathrm{C}_{\mathrm{T}}$ \\
\hline Brain & 31.021900177 \\
Eye & 31.188400269 \\
Gill & 30.866903305 \\
Intestin & 32.704456329 \\
Kidney & 31.963361740 \\
Liver & 32.925949097 \\
Muscle & 30.991914749 \\
Spleen & 28.597431183 \\
Stomach & 33.255867004 \\
\hline
\end{tabular}


$\mathbf{A}$

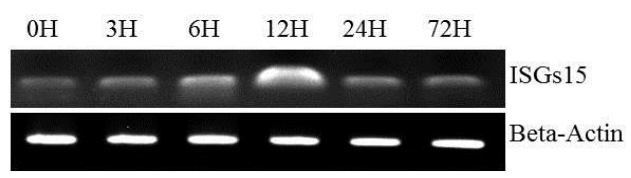

B

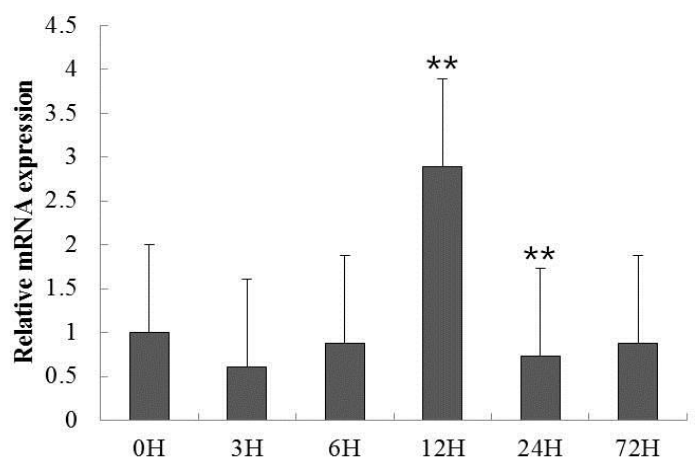

Fig. 2. Temporal expression analysis of ISG15 following rock bream iridovirus (RSIV) infection in whole fish. (A) Reverse transcription (RT)-PCR was performed with $1 \mu \mathrm{g}$ of total RNA using ISG15-qRT$1 \mathrm{~F}$ and $1 \mathrm{R}$ primers. Beta-actin was included in all reactions to verify equal complementary DNA concentrations in the PCR reaction and on the gel. (B) qRT-PCR analysis of ISG15 in rock bream following RSIV infection at 0, 3, 6, 12, 24, and $72 \mathrm{~h}$. Each experiment was performed in triplicate and the expression levels of beta actin and ISG15 at $0 \mathrm{~h}$ were set as 1 . Asterisks indicate statistically significant differences $\left({ }^{*} p<0.05 ;{ }^{* *} p<0.01\right)$ compared with $0 \mathrm{~h}$.

the highest expression level was detected in the kidney, where ISG15 mRNA levels were significantly induced after $1 \mathrm{~h}$ (1.3-fold), peaked at $24 \mathrm{~h}$ (123.3-fold), and decreased at $72 \mathrm{~h}$ (24.3-fold) (Fig. 3A). In muscle, ISG15 mRNA was significantly induced after $3 \mathrm{~h}$ (3.0-fold), peaked at $6 \mathrm{~h}$ (15.5-fold), and decreased at $72 \mathrm{~h}$ (4.7-fold) (Fig. 3B). Similar to muscle in RSIV-infected rock bream, the expression of ISG15 mRNA was induced following RSIV infection in the spleen (1.5-fold at $3 \mathrm{~h}$ post-infection, 3.65 -fold at $6 \mathrm{~h}$ post-infection, and 1.16-fold at $72 \mathrm{~h}$ postinfection) (Fig. 3C). In contrast, the expression levels of ISG15 during RSIV challenge in the gill and liver remained virtually unchanged (data not shown).
A

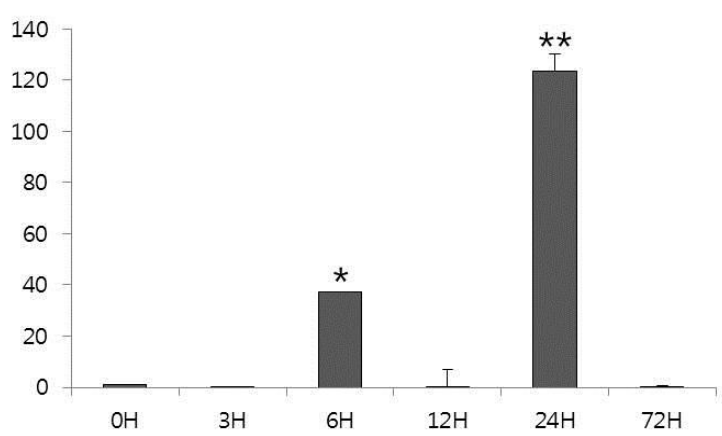

B

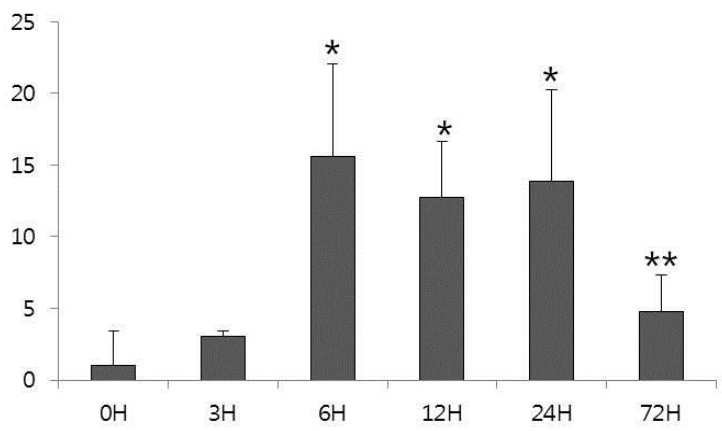

C

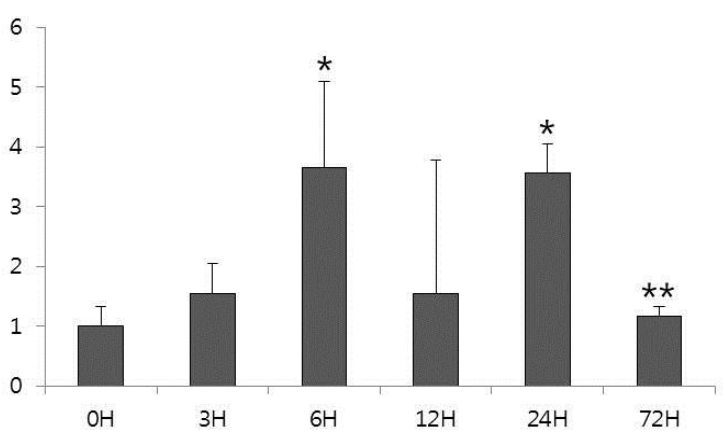

Fig. 3. Temporal distribution of ISG15 mRNA in various tissues following RSIV infection. (A) The expression level of ISG15 was determined in the (A) kidney, (B) muscle, and (C) spleen with qRT-PCR. The samples were analyzed at $0,3,6,12,24$, and 72 hours post-injection. Each experiment was performed in triplicate and the expression levels of beta actin and ISG15 at $0 \mathrm{~h}$ were set as 1 . Asterisks indicate statistically significant differences $\left({ }^{*} p<\right.$ $\left.0.05 ;{ }^{* *} p<0.01\right)$ compared with $0 \mathrm{~h}$.

\section{DISCUSSION}

Rock bream is an economically important aquaculture species, but the damage caused by diseases is increasing. 
Therefore, to reduce these damages, it will be necessary to understand its immune responses and study its immune system. ISG15 is a small ubiquitin-like protein that plays an important role in mammalian immunity by covalently binding target proteins in a process known as ISGylation (O'Farrell et al., 2002; Schneider et al., 2014). ISG15 has been identified in many species, including zebrafish (Langevin et al., 2013), orange-spotted grouper (Huang et al., 2013), Atlantic cod (Furnes et al., 2009), and tongue sole (Wang et al., 2012), and is induced by IFN. Although ISG15 is known to interfere with viral replication and infectivity to limit intracellular viral infections, the detailed antiviral mechanism is not yet known (Durfee et al., 2010; Poynter et al., 2016).

In this study, we analyzed ISG15 mRNA levels from various healthy tissues in rock bream (Fig. 2). qRT-PCR analysis showed that the ISG15 gene was universally expressed in all tissues. Similarly, Liu et al. (2010) reported that the ISG15 gene can be expressed in all tissues in the red drum, and that the expression level of the ISG15 gene in the liver was the highest among the examined tissues. However, no significant induction of ISG15 expression was observed during RSIV infection, likely because the basal level of ISG15 was enough to cope with the stress induced by RSIV infection.

The expression of ISG15 is influenced by pathogenic infection (Dao \& Zhang, 2005; Liu et al., 2010). Previous studies have shown that ISG15 exhibits antiviral activity and can inhibit the production of a wide range of DNA and RNA viruses (Lenschow et al., 2007, Harty et al., 2009). We analyzed the expression levels of ISG15 mRNA in young rock bream following artificial RSIV infection (Fig. 3). RT-PCR analysis indicated that ISG15 was expressed ubiquitously at all times, but significantly increased at $12 \mathrm{~h}$. ISG15 mRNA levels were significantly induced after $6 \mathrm{~h}$, peaked at $12 \mathrm{~h}$, and decreased at $24 \mathrm{~h}$. These results indicate that ISG15 mRNA levels respond quickly to RSIV stimulation (Dao \& Zhang., 2005). ISG15 is known to re- spond quickly to IFN and virus treatments and similar patterns of expression have been reported in several species (Seppola et al., 2007; Kim et al., 2010; Liu et al., 2010; Huang et al., 2013).

Following RSIV infection, rock bream ISG15 expression was acutely increased in the kidney, muscle, and spleen at $6 \mathrm{~h}$ and decreased at $72 \mathrm{~h}$ post-infection. Expression patterns of ISG15 mRNA following RSIV infection were similar. ISG15 expression in uninfected kidneys of rock bream was low compared to other tissues, but in RSIV-infected tissues, expression was high at $24 \mathrm{~h}$. Based on these results, the changes in the temporal expression of ISG15 in the kidney were induced by RSIV infection. According to Wang et al. (2012), the expression of Cynoglossus semilaevis ISG15 (CSISG15) is increased by microbial pathogens, and CSISG15 is released into the extracellular environment following viral infection. Thus, the CSISG15 protein likely acts as a cytokine to activate various immune cell responses.

These results suggest that ISG15 is regulated by the antiviral immune system. This study contributes to our understanding of the rock bream immune system. The expression pattern of ISG15 differed between the whole body and specific tissues following RSIV infection. Therefore, it will be necessary to study the expression of ISG15 based on growth differences in rock bream.

\section{ACKNOWLEDGEMENTS}

This work was supported by a grant from the National Institute of Fisheries Science (R2017001).

\section{REFERENCES}

Baeck GW, Kim JW, Park CI (2008) Identification and expression analysis of an interferon stimulated gene 15 (ISG15) from black rockfish, Sebastes schlegeli. Fish Shellfish Immunol 25:679-681. 
Cho YS, Choi BN, Kim KH, Kim SK, Kim DS, Bang IC, Nam YK (2006) Differential expression of $\mathrm{Cu} / \mathrm{Zn} \mathrm{su}-$ peroxide dismutase mRNA during exposures to heavy metals in rockbream (Oplegnathus fasciatus). Aquaculture 253:667-679.

Chua FHC, Ng NL, Ng KL, Loo JJ, Wee JY (1994) Investigation of outbreaks of a novel disease, 'sleepy grouper disease', affecting the brown-spotted grouper, Epinephelus tauvina Forskal. J Fish Diseases 17:417-427.

Collet B, Secombes CJ (2002) Type I-interferon signalling in fish. Fish Shellfish Immunol 12:389-397.

D’Cunha J, Knight Jr E, Haas AL, Truitt RL, Borden EC (1996) Immunoregulatory properties of ISG15, an interferoninduced cytokine. Proc Natl Acad Sci USA 93: 211-215.

Dao CT, Zhang DE (2005) ISG15: A ubiquitin-like enigma. Front Biosci 10: 2701e22.

Durfee LA, Lyon N, Seo K, Huibregtse JM (2010) The ISG15 conjugation system broadly targets newly synthesized proteins: Implications for the antiviral function of ISG15. Mol Cell 38:722e732.

Farrell PJ, Broeze RJ, Lengyel P (1979) Accumulation of an mRNA and protein in interferon-treated Ehrlich ascites tumour cells. Nature 279:523-525.

Furnes C, Kileng Ø, Hanssen C, Seppola M, Jensen I, Robertsen B (2009) Atlantic cod (Gadus morhua L.) possesses three homologues of ISG15 with different expression kinetics and conjugation properties. Dev Comp Immunol 33:1239e1246.

Harty RN, Pitha PM, Okumura A (2009) Antiviral activity of innate immune protein ISG15. J Innate Immun 1: $397 \mathrm{e} 404$.

Huang X, Huang Y, Cai J, Wei S, Ouyang Z, Qin Q (2013) Molecular cloning, expression and functional analysis of ISG15 in orange-spotted grouper, Epinephelus coioides. Fish Shellfish Immunol 34:1094e1102.

Inouye K, Yamano K, Maeno Y, Nakajima K, Matsuoka M, Wada Y, Sorimachi M (1992) Iridovirus infection of cultured red sea bream Pagrus major. Fish Pathology 27:19-27.

Jung S, Oh M (2000) Iridovirus-like infection associated with high mortalities of striped beakperch, Oplegnathus fasciatus (Temminck et Schlegel), in southern coastal areas of the Korean peninsula. J Fish Diseases $23: 223-226$.

Jung S, Miyazaki T, Miyata M, Danayadol Y, Tanaka S (1997) Pathogenicity of iridovirus from Japan and Thailand for the red sea bream Pagrus major in Japan, and histopathology of experimentally infected fish. Fisheries Sci 63:735-740.

Kasornchandra J, Khongpradit R, Flegel MH (1997) Isolation and preliminary characterization of a pathogenic iridovirus agent in nursing grouper, Epinephelus malabaricus. In: MacRae TW, MacRae IH (Eds), Diseases in Asian Aquaculture III. FHS/AFS Manila pp. 61-66.

Langevin C, van der Aa LM, Houel A, Torhy C, Briolat V, Lunazzi A, Harmache A, Bremont M, Levraud JP, Boudinot P (2013) Zebrafish ISG15 exerts a strong antiviral activity against RNA and DNA viruses and regulates the interferon response. J Virol 87:10025e10036.

Lee YM, Yang IJ, Noh JK, Kim HC, Park CJ, Park JW, Noh GE, Kim WJ, Kim KK (2016) Expression analysis of lily type lectin isotypes in the rock bream, Oplegnathus fasciatus: in the tissue, developmental stage and viral infection. Dev Reprod 20:297-304.

Lenschow DJ, Giannakopoulos NV, Gunn LJ, Johnston C, O'Guin AK, Schmidt RE, Levine B, Virgin IV HW (2005) Identification of interferonstimulated gene 15 as an antiviral molecule during Sindbis virus infection in vivo. J Virol 79:13974-13983.

Lenschow DJ, Lai C, Frias-Staheli N, Giannakopoulos NV, Lutz A, et al. (2007) IFN-stimulated gene 15 functions as a critical antiviral molecule against influenza, herpes, and Sindbis viruses. Proc Natl Acad Sci USA 104: 1371-1376.

Lin JY, Hu GB, Liu DH, Li S, Liu QM, Zhang SC (2015) 
Molecular cloning and expression analysis of interferon stimulated gene 15 (ISG15) in turbot, Scophthalmus maximus. Fish Shellfish Immunol 45:895-900.

Liu C-S, Sun Y, Zhang M, Sun L (2010) Identification and analysis of a Sciaenops ocellatus ISG15 homologue that is involved in host immune defense against bacterial infection. Fish Shellfish Immunol 29:167-174.

Loeb KR, Haas AL (1992) The interferon-inducible 15$\mathrm{kDa}$ ubiquitin homolog conjugates to intracellular proteins. J Biol Chem 267:7806e7813.

Loeb KR, Haas AL (1994) Conjugates of ubiquitin crossreactive protein distribute in a cytoskeletal pattern. Mol Cell Biol 14:8408-8419.

Magnadóttir, B (2006) Innate immunity of fish (overview). Fish Shellfish Immunol 20:137-151.

Medzhitov R, Janeway CA (1997) Innate immunity: the virtues of a nonclonal system of recognition. Cell 91: 295-298.

Miyata M, Matsuno K, Jung S, Danayadol Y, Miyazaki T (1997) Genetic similarity of iridoviruses from Japan and Thailand. J Fish Diseases 20:127-134.

Moreno P, Garcia-Rosado E, Borrego JJ, Alonso MC (2016) Genetic characterization and transcription analyses of the European sea bass (Dicentrarchus labrax) isg15 gene. Fish Shellfish Immunol 55:642-646.

Motoshige Y, Hidehiro K, Ikuo H, Takashi A (2011) Identification and characterization of Japanese flounder, $\mathrm{Pa}$ ralichthys olivaceus interferon-stimulated gene 15 (JfISG15). Comp Immunol Microbiol Infect Dis 34:83-91.

Nakajima K, Maeno Y (1998) Pathogenicity of red sea bream iridovirus and other fish iridoviruses to red sea bream. Fish Pathol 33:143-144.

O'Farrell C, Vaghefi N, Cantonnet M, Buteau B, Boudinot P, Benmansour A (2002) Survey of transcript expression in rainbow trout leukocytes reveals a major contribution of interferon-responsive genes in the early response to a rhabdovirus infection. J Virol 76:8040e8049.

Oh DJ, Kim JY, Lee JA, Yoon WJ, Park SY, Jung YH (2007)
Complete mitochondrial genome of the rock bream Oplegnathus fasciatus (Perciformes, Oplegnathidae) with phylogenetic considerations. Gene 392: 174-180.

Øvergård AC, Nerland AH, Fiksdal IU, Patel S (2012). Atlantic halibut experimentally infected with nodavirus shows increased levels of T-cell marker and IFN $\gamma$ transcripts. Dev Comp Immunol 37:139-150.

Pfaffl MW (2001) A new mathematical model for relative quantification in real-time RT-PCR. Nucleic Acids Res 29:e45.

Poynter SJ, Stephanie J, Dewitte ORR (2016) Fish interferon-stimulated genes: The antiviral effectors. Dev Comp Immunol 65:218-225.

Robertsen B (2006) The interferon system of teleost fish. Fish Shellfish Immunol 20:172-191.

Sarkar SN, Sen GC (2004) Novel functions of proteins encoded by viral stress-inducible genes. Pharmacol Ther 103:245-259.

Schneider WM, Chevillotte MD, Rice CM (2014) Interferon-stimulated genes: a complex web of host defenses. Annu Rev Immunol 32:513e545.

Schultz U, Kaspers B, Staeheli P (2004) The interferon system of nonmammalian vertebrates. Dev Comp Immunol 28:499-508.

Seppola M, Stenvik J, Steiro K, Solstad T, Robertsen B, Jensen I (2007) Sequence and expression analysis of an interferon stimulated gene (ISG15) from Atlantic cod (Gadus morhua L.). Dev Comp Immunol 31:156-171.

Umasuthan N, Revathy KS, Bathige SD, Lim BS, Park MA, Whang I, Lee J (2013) A manganese superoxide dismutase with potent antioxidant activity identified from Oplegnathus fasciatus: Genomic structure and transcriptional characterization. Fish Shellfish Immunol 34:23-37.

Wang W, Zhang M, Xiao ZZ, Sun L (2012) Cynoglossus semilaevis ISG15: a secreted cytokine-like protein that stimulates antiviral immune response in a LRGG motif-dependent manner. PLoS One 7:1e11. 